УДК 297.18

DOI 10.35423/2078-8142.2021.2.1.11

Таміла Абдуллаєва аспірантка кафедри богослов'я та релігієзнавства Національного педагогічного університету імені М. П. Драгоманова, м. Київ, Украӥна e-mail: abdullaieva7814-1@uoel.uk ORCID: https://orcid.org/0000-0003-2112-8620

Рустам Гафурі кафедра богослов'я та релігієзнавства Національного педагогічного університету імені М. П. Драгоманова, м. Київ, Україна e-mail: gafuri@lund-univer.eu ORCID: https://orcid.org/0000-0002-0454-2697

Хайсам Аzа аспірант кафедри богослов'я та релігієзнавства Національного педагогічного університету імені М. П. Драгоманова, м. Київ, Украӥна e-mail: kh.aga@copenhagen-university.com ORCID: https://orcid.org/0000-0002-2430-5007

\title{
ХАРАКТЕРИСТИКА РІДКІСНИХ ВИДІВ ХАДИСІВ ТА ЇХ ВАЖЛИВІСТЬ ДЛЯ НАУКИ ХАДИСОЗНАВСТВА
}

У сучасному світі близько 1 млрд. людей в азіатських $i$ африканських, частково європейських і американських краӥнах, які у своєму мисленні та щоденній практиці звертаються до священних текстів про пророка Мухаммада, його Сунни, щьоб не лише знайти прийнятні відповіді на питання побутового характеру, а й вирішити проблеми, щчо стосуються сфери соціально-політичного розвитку, а також міжнародних відносин. Метою даної статті $\epsilon$ дослідження рідкісних видів хадисів шляхом вивчення прпаць сучасних та класичних теологів ісламу. Новизна иього дослідження полягає в тому, що в ньому зроблена спроба контекстуального $i$

(C) Таміла Абдуллаєва, Рустам Гафурі, Хайсам Ага, 2021 
порівняльного аналізу рідкісних видів хадисів. Наголошено на важливості правильного розуміння висловів, аби не загубитись у системі ієрархї хадисів у цілому. Незнання тонкощів хадисознавства може призвести до непробачливих помилок при тлумаченні хадисів. I, на жаль, у наш вік набули розповсюдження екстремістські секти, які неправильно й оманливо тлумачать хадиси, ілюструючи вищезгадану необізнаність.

Ключові слова: пророча традичія, ланцююг передавачів, іслам, Сунна, теологія, релігієзнавство.

Світові ісламознавці відзначають недостатню вивченість хадисної літератури [1-3], тому актуальність наукового пошуку в даному напрямку не викликає сумніву, оскільки сама проблематика релігійної науки про хадиси диктує необхідність теоретичних i прикладних досліджень у сфері хадисознавства, зближення суто богословських і наукових точок зору на це унікальне явище ісламської культури. Хадисні тексти не повною мірою розглянуті і як джерело для наукового дослідження процесу формування ісламської догматико-правової системи. А якщо казати про рідкісні різновиди хадисів, то їм не приділяється належної уваги.

В основі представленого дослідження лежить класифікація хадисів. Алій - це Хадис, в якому менша чисельність передавачів ланцюгом, а назіль - це його антонім. Маукуф - це хадис, чий ланцюг доходить до сподвижників, але, незважаючи на те, мова це або дія, він не доходить до Пророка. Хадис мурсаль - це хадис, у якому пропущено ім'я сподвижника. Хадис горіб - це хадис, який переказує один передавач. Хадис мункаті - це хадис, у якому відсутній передавач у ланцюгу. У ланцюзі хадису мудаль пропущені два передавача. Хадис маклюб буває двох видів: заміна місця одного передавача замість іншого, а також заміна ланцюга одного хадиса на ланцюг іншого. Хадис алій і хадис назіль означють «високий» i «низький», і мається на увазі не критика хадисів. Ця назва має на меті відрізняти два види. Високий - це той хадис, в якому менша чисельність передавачів його ланцюгом, а низький - це антонім, в якому перераховано багато передавачів.

Хадис маукуф - це хадис, чий ланцюг доходить до сподвижників, незважаючи на те, мова це або дія, і не доходить до Пророка 
[4]. Це такий текст, який при посиланні доходить до сподвижників і не переходить до самого Пророка Мухаммада, чистий від передумови, що він йде до самого Пророка. Маукуф означає «зупинка», тобто він зупинився на сподвижниках. Ібн Масуд стверджував, що завжди варто дивитися в Мусхаф, тобто завжди читати Коран [5]. Такий хадис має ступінь маукуф за ланцюгом і $є$ сохіх, тобто повністю достовірним. Також варто зазначити, що у сподвижника немає можливості вносити свою думку або свої висновки до хадису, тим паче якщо він $\epsilon$ марфу, тобто в підсумку доходить до Пророка. Гарним прикладом для цього випадку можна вважати мову Абу Гурайри і Джабіра [6].

Хадис мурсаль - це хадис, у якому пропущено ім'я сподвижника. «Аль-мурсаль», згідно з арабською мовою, взято від слова «ірсаль», що означає «послання», інші значення: «відправник», «послання». Згідно $з$ арабською мовою, «послав» вживається тоді, коли що-небудь уже відправлено без перешкод, наприклад, радіостанція, звідки йде сигнал - передача. Аль-мурсаль - це хадис, в ланцюгу якого пропущено ім'я сподвижника [7]. Це означає, що коли ланцюг доходить до ат-табіін, він відразу переходить до Пророка, пропускаючи сподвижника. Ат-табіін Саїд ібн Мусайяб або АзЗухрі або Аль-Хасан Аль-Басрі 3 цього приводу стверджував: «Пропускаючи ім'я сподвижника, хадис йде від них. Яхья ібн Саід Аль-Ансарі або Аз-Зухрі - вони табі согир, або табі кабір, як Убайдуллаг» [8], де табіін согир - передавач, більшість передач якого йдуть від подібних до табі, а табі кабір - від сподвижників. Але це в разі, якщо табі сам не чув те, що передано від самого Пророка. Якби він чув безпосередньо від Пророка, то вийшов би хадис іттісоль, а не ірсаль. Безпосередній зв'язок був би від самого Пророка [9].

Невідомість кого-небудь зі сподвижників не завдає жодної шкоди. Якщо усі є сподвижниками, то передача прийнята, незважаючи на те, що ім'я одного з них пропущене. Мурсаль ат-табіій це випадок, коли пропущений не лише сподвижник, а й табі. Таким чином, як висновок відзначимо, що більшість мовознавців дійшли консенсусу, що мурсаль дає хадису ступінь доіф. Тобто не використовується для будь-якого доказу, оскільки немає відомості щодо 
пропущеного в існаді, і є ймовірність, що пропущено більше, ніж одну людину, може і табі, не тільки сподвижник.

Хадис горіб - це хадис, який повністю або частково переказує один передавач на всіх етапах передачі на одній ланці ланцюга. Трапляються випадки, коли хадис є горіб за його ланцюгом передач, а не за самим текстом. Це не означає, що текст хадису один, навпаки, - може бути, що багато хто слухав цей хадис. Наприклад, якщо відомо, що який-небудь хадис передала група сподвижників, то це не виключає того, що може бути й інший ланцюг передачі цього хадису [10]. Група отримала цей текст і передала, а також одна окрема людина чула цей самий хадис і передала. У такому разі з'являється другий напрям, який і називатиметься горіб. Сам текст у такому випадку не є горібом, оскільки існує ще одна група передачі [11].

Хадис аль-мункаті - це хадис, у ланцюгу якого відсутні один або декілька передавачів, пропущені підряд, або на різних позиціях. I якщо в різних положеннях або місцях повторювався пропуск передавача, і в кожному місці один раз, то ланцюг вважається перерваним в кількох місцях. С два типи хадису мудалляс: коли пропускається ім'я одного 3 передавачів і використовуються слова «від» і «що», наприклад, «від тієї особи передано, що інший сказав...»; коли за ланцюгом передавача не пропущено, але на нього посилаються і описують таким чином, що неможливо зрозуміти, Хто він.

Теологи Ібн Ас-Солях і Ан-Науауій стверджували, що тадліс («прихованість») трапляється в одному 3 двох видів: або прихованість у ланцюгу, або прихованість в інформованості про особистість передавача [5; 6]. Перший вигляд - це прихованість у процесі передачі, тобто пропускається ім'я шейха, який передав йому цей хадис, наприклад, з причини того, що він належить до осіб, що мають послаблену передачу (погана запам'ятовуваність тексту). Тоді передавач пропускає шейха й передає цей хадис від того, хто був перед шейхом, тобто від того, кого шейх зустрічав при житті, або від того сучасника, від якого він сам особисто не чув [11].

Шейх Абдуллага аль-Гарарій - ісламський теолог, знавець хадисів, засновник перебігу хабашитів. Він негативно ставився до Ібн Таймії, та стверджував, що переконання Ібн Таймії не відпові- 
дають ісламу. Хабашити (його послідовники) стверджують, що вони слідують шафіїтському мазхабу в питаннях фікха, а в питаннях віробачення вони ашарити і мурджіїти. Хабашити дотримуються двох суфійських тарікатів: Рифая та Кадирія [12].

Мудалліс - це людина, яка приховує учасника ланцюга. При цьому він повинен бути сучасником того, від кого передається. Тобто можливі випадки, що вони зустрічалися, але особисто від приховуваного передавач нічого не чув, або чув деякі хадиси, а інші отримав від кого-небудь ще. А якщо хадис передається від того, 3 ким передавач не зустрічався і 3 ким не був сучасником, то така передача вважається непевною, оскільки зрозуміло, що той, хто передає, не хоче, щоб люди подумали, що він безпосередньо чув слова. Хадис має прихованість у ланцюзі, коли передавач переказує хадис від того, хто вносить в ланцюг послаблення, тобто має недолік в якості передачі. Тому, коли він пропускає цього послаблювача і передає від шейха, використовуючи прийменник «від», достовірність ланцюга вирівнюється. Спостерігач, який вивчає цей ланцюг, може думати, що весь він має достовірність. Наприклад, Баки ібн аль-Валідія Ісхак ібн Рохауай передав від Баки ібн альУалідія, сказавши: «Розповідав мені Абу Уаггаб Аль-Асдию від Ан-Нафіга від сина дядька Пророка», - і далі він розповів хадис. Та Баки назвав Уаггаб бін Убайдуллаг ібн Амра по-іншому, тобто не Убайдуллаг, а Абу Уаггаб. Однак це не є оманою, а лише прихованістю, і розпізнавати цю особистість довелося, виходячи з того, яке ім'я назване.

Треба зауважити, що будь-який додаток, який виніс передавач зі ступенем сохіх або хасан, є прийнятим, поки він не буде мати таку оцінку, яка суперечить іншій, більш достовірній передачі. Тобто доти, доки той, хто є більш достовірним, не зробив додаток, тому що останній не суперечить іншій передачі, в якій не згаданий цей додаток. У цьому випадку додаток приймається абсолютно без труднощів. Таким чином приймається і весь хадис, і приймається від одного шейха, але не від іншого. Тобто цей хадис, який вже 3 додатком, вже ніби новий хадис, але, водночас, майже ідентичний попередньому [12]. I другий випадок, коли додаток суперечить іншому. У такому випадку він не приймається відразу, - і доведеться 
аналізувати його по відношенню до інших хадисів, у яких немає такого додатка. Це така передача, в якій буде зважування переваги - брати чи ні. Тому приймається та передача, яка перевершує іншу, вона має назву «махфуз», тобто, «збережений, оптимальний», а те, що в результаті не приймається, називають «шаз» [13]. Таким чином, коли немає можливості об'єднати або знайти спільне, то виходить, що є перевага одного виду хадису над іншим саме тому, що передача групи достовірних сильніша, ніж у одного достовірного.

Трапляються також випадки, коли один достовірний відрізняється від іншого достовірного у тому, що запам'ятовує сильніше. Такий хадис теж називається шаз. Це в тому випадку, коли немає можливості зняти протиріччя. Тому коли передає той, у кого пам'ять краща, він має перевагу при прийнятті. Ат-Тірмізі, Ан-Насаі і Ібн Маджаг передав від Амара ібн Динара, від Аусаджа, від Ібн Аббаса, що за життя Пророка один чоловік помер і не залишив після себе жодного спадкоємця, крім одного слуги, якого він звільнив від рабства, тоді Пророк виніс рішення віддати йому спадок колишнього господаря. Є два ланцюга: в одній Ат-Тірмізі, Ан-Насаі і Ібн Маджаг, а другий - Хамам ібн Зайд, через кілька ланок, від Ібн Аббаса і відразу посилався на Пророка. Незважаючи на те, що Хамам достовірний і добре запам'ятовує текст, передача 3 ним не береться, тому що перервано ланцюг [14].

Хадис аль-фард або єдиний - це той хадис, який обмежується одним достовірним передавачем. Тобто передача дійшла по тексту або за ланцюгом, і передавала іï тільки одна особа. Хадис фард ділиться на 2 види: мутлак - тобто унікальний, абсолютно єдиний, - це той хадис, який передає виключно один. Наприклад, хадис, в якому є заборона продажу спадщини, яку отримує той, який звільнив від рабства свого раба, - і спадок йде колишньому господареві і це дарується йому. Передав це виключно Абдуллаһ Ібн Динар від одного Ібн Умара. Іншій вид хадису фард - це фард ан-нісба, що означає «відносність». Наприклад, хадис, обмежений певною місцевістю, передав Абу Давуд від Абу Аль-Валід Ат-Таялусій від Хаммама від Катада від Абу Саїда Аль-Худрій про те, що: «Наказав нам Посланник Аллаһа читати Аль-Фатиху і те що є з Курана». Аль-Хакім стверджував, що унікальність даного хадиса полягає в 
тому, що єдиний, хто передав, що пророк наказав таке, - це жителі Аль-Басри від початку до кінця ланцюжка [15].

Хадис муальаль - це такий хадис, який за зовнішніми якостями можна назвати повноцінним хадисом, тобто в ньому немає нічого підозрілого, але після того, як компетентні теологи провели дослідження, в ньому було виявлено дефект або в ланцюгу, або в тексті [16]. Це виявляється, коли теологи різними шляхами збирають ланцюги, а також перевіряють, наскільки якісно збережені тексти, і у результаті бачать протиріччя. I в результаті цього дослідження і вивчення, вчені бачать, що один передавач відрізняється від інших, а також спостерігають, як запам'ятовувався цей хадис, враховуючи чисельність тих, хто передав ці хадиси.

Наприклад, Хадис Ібн Джаріра від Муси Бін Укба, від Сугейль Ібн Абу Соліха від Абу Гурайри, який означає, що хто сидить на зборах, і в кому є щось неприємне - плітки, обман, лицемірство - то нехай скаже перед тим, як встати звідти: «Субханаллагумма уа біхамдіка» (висловлюємо наше вихваляння Аллаху). Ступінь марфу, тобто передано безперервно від Пророка Мухаммада, цьому хадису дали таки хадисознавці, як Ат-Тірмізі, Ібн Хіббан і Аль-Хакама. Проте хадисознавець Хакім стверджував, що цей хадис, якщо судити із зовнішнього стану, має всі умови для ступеня сохіх, але в ньому наявний дефект в ланцюгу, тому що Муса Ібн Укба не чув цей хадис від Сугейль Ібн Абу Соліх, а той, хто чув від нього - це Муса Ібн Ісмаіль. Тобто помилилися про по батькові Муси, а також пропущене одне ім'я в ланцюгу. Отже, незнання тонкощів хадисознавства може призвести до непробачливих помилок при тлумаченні хадисів. I, на жаль, у наш вік набули розповсюдження екстремістські секти, які неправильно й оманливо тлумачать хадиси, ілюструючи вищезгадану необізнаність.

\section{ЛІТЕРАТУРА}

1. Аль-Хайсами А. Б. Абу Бакр. Маджма' аз-Заваид. Каир : Кудси, 1952.

2. Аль-Бухари М. Б. Исма'ил. Аль-Джами' ас-сахих. М. : Благотворительный Фонд «Ибрагим бин Абдулазиз Аль Ибрагим», 2002. 
3. Аш-Шаукани М. Б. А. Нейл ал-Аутар Шарх Мунтака аль-Ахбар. Дамаск : Дар аль-Хейр, 1918.

4. Ибн Ханбал. Муснад. Каир : Кудси, 1913.

5. Аль-Хадис У. Ли ибн ас-Салях. Аль-имам Абу Амр Усман ибн Абдуррахман аш-Шахразури. Тахкик ва шарх Нуруд-Дин 'Итр. Димашк : Даруль-Фикр, 1984.

6. Ан-Наави Йахйа Б. Ш. Сады праведных. М. : Бадр, 2002.

7. Ал-Аскалани Ибн Хаджар. Булуг аль-Маарам. Баку : Умма, 2002.

8. Даракутни. Сунан. Каир : Кудси, 1963.

9. Дарими А. Б. А. Р. Сунан. Дамаск : Дар аль-Хейр, 1949.

10. Ибн Хайр М. Б. Х. Фихрист. Багдад : Aleilm, 1963.

11. Шарху аль-Манзума аль-Байкунийя фи Мусталах ал-Хадиси. $A u_{-}$ назим Умар ибн Мухаммад ибн Футух аль-Байкуни ад-Димамки ашШафии. Джам-у ва тартиб -Абдулла Сираджуддин аль-Хусайни. Халеб : Мактабату дару аль-Фалях, 2009.

12. Аль-Кушайри М.Б.Х. Сахих. Каир : Кудси, 1974.

13. Насируддин А. Мусадир аш-ии'р аль-джахили. Каир : Да-руль Маариф, 1962.

14. Ат-Тирмизи ибн-Иса М. Сунан. Каир : Кудси, 1975.

15. Муртазин М. Введение в коранические науки. Москва: Московский исламский университет, 2006.

16. Сираджуддин аль-Хусайни А. А. Комментарии $\kappa$ аль-манзума аль-Байкуния. Казань : Казанский федеральный университет, 2014.

\section{REFERENCES}

Al-Haysami, A.B. (1952). Abu Bakr. Majma 'al-Zawaid. Cairo: Qudsey.

Al-Bukhari, M.B. (2002). Ismail. Al-Jami 'as-sahih. Moscow: Ibrahim bin Abdulaziz Al Ibrahim Charitable Foundation.

Ash-Shaukani, M.B.A. (1918). Neil al-Autar Sharh Muntaka al-Akhbar. Damascus: Dar al-Kheir.

Ibn Hanbal. (1913). Musnad. Cairo: Qudsey.

al-Hadith, W. (1984). Li ibn al-Salah. Al-Imam Abu Amr Usman ibn Abdurrahman al-Shahrazuri. Tahkik wa sharh Nurud-Din 'Itr. Dimashki: Darul-Fikr.

An-Naawi Yahya, B.Sh. (2002). Gardens of the righteous. Moscow: Badr.

Al-Askalani Ibn Hajar. (2002). Bulug al-Maaram. Baku: Ummah. 
Darakutni. (1963). Sunan. Cairo: Qudsey.

Darimi, A.B.A.R. (1949). Sunan. Damascus: Dar al-Kheir.

Ibn Khair, M.B.Kh. (1963). The Fihrist. Baghdad: Aleilm.

Sharhu al-Manzuma al-Baykuniyya fi Mustalah al-Hadisi. (2009). An-Nazim Umar ibn Muhammad ibn Futuh al-Baykuni ad-Dimashki al-Shafi'i. Jam-u wa tartib -Abdullah Sirajuddin al-Husayni. Aleppo: Maktabatu Daru al-Fallah.

Al-Kushairi, M.B.H. (1974). Saheeh. Cairo: Qudsey.

Nasiruddin, A. (1962). Musadir al-shi'r al-jahili. Cairo: Yes-rudder Maarif.

At-Tirmidhi ibn-Isa, M. (1375). Sunan. Cairo: Qudsey.

Murtazin, M. (2006). Introduction to the Quranic Sciences. Moscow: Moscow Islamic University.

Sirajuddin al-Husayni, A.A. (2014). Commentaries on al-Manzuma alBaykuniya. Kazan: Kazan Federal University.

\section{Tamila Abdullaieva}

Post-Graduate Student, the Department of Theology and Religious Studies, National Pedagogical Dragomanov University; Kyiv, Ukraine; e-mail: abdullaieva7814-1@uoel.uk; ORCID: https://orcid.org/0000-0003-2112-8620

\section{Rustam Gafuri}

Department of Theology and Religious Studies, National Pedagogical Dragomanov University; Kyiv, Ukraine; e-mail: gafuri@lund-univer.eu; ORCID: https://orcid.org/0000-0002-0454-2697

\section{Khaisam Aga}

Post-Graduate Student, the Department of Theology and Religious Studies, National Pedagogical Dragomanov University; Kyiv, Ukraine; e-mail: kh.aga@copenhagen-university.com; ORCID: https://orcid.org/0000-00022430-5007

\section{Characteristics of Rare Types of Hadiths and their Importance for the Sci- ence of Hadith Studies}




\begin{abstract}
In the modern world, about 1 billion people in Asian and African, partly European and American countries, who in their thinking and daily practice turn to the sacred texts about the Prophet Muhammad, his Sunnah, to find acceptable answers not only to questions of a domestic nature, but also to solve problems related to the sphere of socio-political development, as well as international relations. The purpose of this article is to study rare types of hadith by studying the works of modern and classical theologians of Islam. The novelty of this study is that it attempts a contextual and comparative analysis of rare types of hadith. Aliy is the Hadith in which the number of transmitters in the chain is smaller, and unfortunately it is its antonym. Maukuf is a hadith whose chain reaches the companions, but whether it is speech or action, it does not reach the Prophet. A hadith mursal is a hadith in which the name of a companion is omitted. The hadith of a mushroom is a hadith narrated by one transmitter. The hadith of munkati is a hadith in which there is no transmitter in the chain. Two transmitters are missed in the chain of hadith modal. There are two types of hadith maklub: replacing the location of one transmitter instead of another, and replacing the chain of one hadith with the circuit of another. Other rare types of hadiths have also been studied. The importance of a correct understanding of these catches is emphasized, so as not to get lost in the system of the hadith hierarchy as a whole. Ignorance of the subtleties of hadith studies can lead to unforgivable errors in the interpretation of hadiths. And, unfortunately, extremist sects have become widespread in our age, which misinterpret and mislead hadiths, illustrating the above-mentioned ignorance.
\end{abstract}

Keywords: prophetic tradition, chain of transmitters, Islam, Sunnah, theology, religious studies. 